\title{
Diversity and abundance of terrestrial Gastropods on the slopes of Mount Arjuna-Welirang, East Java, Indonesia
}

\author{
PUTRI AFIN NURHAYATI ${ }^{1, \boldsymbol{v}}$, MOCH AFFANDI ${ }^{1}$, AYU SAVITRI NURINSIYAH ${ }^{2, \boldsymbol{v v}}$ \\ ${ }^{1}$ Department of Biology, Faculty of Science and Technology, Universitas Airlangga. Jl. Dr. Ir. Soekarno, Mulyorejo, Surabaya 60115, East Java, \\ Indonesia. Tel./fax.: +62-31-5915551, `email: nurhayatiafin@gmail.com \\ ${ }^{2}$ Museum Zoologicum Bogoriense, Research Center for Biology, National Research and Innovation Agency. Jl. Raya Jakarta-Bogor Km. 46, Cibinong, \\ Bogor 16911, West Java, Indonesia. Tel.: +62-21-8752824, Fax.: +62-21-8752929, ^vemail: ayus002@lipi.go.id
}

Manuscript received: 15 July 2021. Revision accepted: 15 September 2021.

\begin{abstract}
Nurhayati PA, Affandi M, Nurinsiyah AS. 2021. Diversity and abundance of terrestrial Gastropods on the slopes of Mount Arjuna-Welirang, East Java, Indonesia. Biodiversitas 22: 4193-4202. Before this study, the latest list of land snail species from Mt. Arjuna-Welirang was published in 1952. The current study aims to update the list of terrestrial Gastropods in the area, focusing on Sumber Brantas Arboretum and Raden Soerjo Forest Park Conservation Area (Tahura), East Java, Indonesia. Live snails and dead shells were collected from $2410 \times 10 \mathrm{~m} 2$ sampling plots to determine species richness, composition, and abundance. Sampling was carried out by combining visual observation (direct collection) and sorting-sieving soil-leaf litter samples. Total 646 specimens belonging to eight families and 13 species were collected, all new records to the area. Thus, the number of species known from Mt. Arjuna-Welirang was increased to 16 species from nine families. The diversity index of the Mt. Arjuna-Welirang slope was 1.1, and the dominance index was 0.54. The Tahura had a higher diversity index than the Arboretum, at 2.0 and 0.38 , respectively, but the dominance index for Tahura was lower (0.18 and 0.85, respectively). This was due to the dominance of Bradybaena similaris, an invasive species in the latter area. Less canopy cover and more human activity in the Arboretum are factors that might cause this discrepancy. Many land snail species are sensitive to desiccation and habitat disturbance. Therefore, minimizing habitat changes and human activities is necessary to maintain or increase native land snail species diversity.
\end{abstract}

Keywords: Arboretum of Sumber Brantas, Raden Soerjo Forest Park, terrestrial gastropods

\section{INTRODUCTION}

The biodiversity of terrestrial Gastropods (land snails and slugs) from Java has been studied by various foreign and local malacologists, yet many species await discovery. In the last decade, 24 new species were discovered and described (Nurinsiyah and Hausdorf 2017a; Nurinsiyah and Hausdorf 2017b; Nurinsiyah et al. 2019a; Greke 2019). This increased the species list from 118 species (Heryanto 2011) to 242 species (Nurinsiyah and Hausdorf 2020) in Java or 255 species if the adjacent islands are included (Nurinsiyah 2018). Although the work on land snails in Java is the most complete compared to other islands in the Indonesian archipelago, monitoring and conserving populations of native species in Java is crucial. For example, diverse land snails are reported from more minor spatial scales or certain particular areas in Java that have not been re-surveyed for decades.

Tropical terrestrial Gastropods prefer moist and rich in organic matter, especially areas rich in calcium carbonate (Maassen 2000; Marwoto 2008). They are generally found on or in between leaf litter, on forest soil surfaces, weathered wood, sometimes underneath live plant leaves, and tall trees in the case of arboreal snails (Heryanto et al. 2003; Marwoto 2016). Many land snail species are siteendemics. For example, 34 of the 122 species in Perak Malaysia are unique to a single limestone hill (Foon et al. 2017), and four of the 14 endemic species of
Diplommatinidae in Java were recorded from a single mountain (Nurinsiyah and Hausdorf 2017b).

Land snails are sensitive to habitat changes. Species richness and composition in an area with intact canopy cover are different (more prosperous and more varied) than areas with more open canopy cover (Nurinsiyah et al. 2016). Anthropogenic effects also influenced the species composition, especially the presence and abundance of non-native species (Nurinsiyah et al. 2016; Nurinsiyah and Hausdorf 2019). Massive land-use changes and the increase of human activity in Java will lead to habitat loss and consequently affect the land snail diversity. Areas with dense canopy cover and less human activity, such as conservation areas, are essential refugia for land snails in Java.

Mount Arjuna-Welirang is one of the mountainous areas in East Java with an elevation of more than 3000 meters above sea level. A portion of it is considered a conservation area. This includes the Sumber Brantas Arboretum and the Raden Soerjo Forest Park (after this referred as Tahura) located on the slopes of the Mountain. Only three species of terrestrial Gastropods have been reported from the Mount Arjuna-Welirang area so far, i.e., Macrochlamys infans, Lissachatina fulica, and Paropeas acutissimum (Benthem-Jutting 1950, 1952). These species lists were from seven decades ago, and therefore there is a need for updated information.

In this research, we observe, monitor, and update the occurrence of terrestrial Gastropods on the slope of Mount 
Arjuna-Welirang, East Java. The research will provide the basis for further action, both conservation and land use in the Mount Arjuna-Welirang area.

\section{MATERIAL AND METHODS}

\section{Study area}

The research was conducted from September 2020 to March 2021. Our research area was located at the slope of Mt. Arjuna-Welirang, East Java, Indonesia explicitly focussing on two locations, i.e., Sumber Brantas Arboretum and Raden Soerjo Forest Park Conservation Area (Tahura), East Java, Indonesia. The areas are between $\mathrm{S} 7^{\circ} 44^{\prime} 30.95^{\prime \prime}$ to $7^{\circ} 58^{\prime} 60.1^{\prime \prime}$ and $\mathrm{E} 112^{\circ} 31^{\prime} 13^{\prime \prime}$ to $112^{\circ} 52^{\prime} 86.96^{\prime \prime}$ (Figure 1). The research area is situated at an elevation between $1500 \mathrm{~m}$ a.s.l. The light intensity in both areas were measured using a lux meter.

Meanwhile, the soil $\mathrm{pH}$ and soil humidity in both areas were measured using a soil tester. The two areas are managed by different organizations, which has led to other environmental and vegetation management in each area. Perum Jasa Tirta contains the Arboretum I, a state-owned company. The foliage in the Arboretum is mainly intentionally planted by the administration and includes pine, mahogany, palm, and false shamrock (Oxalis triangularis) (Figure 2). The Tahura is managed by the Unit Pengelola Teknis (UPT) Tahura Raden Soerjo Environmental Service Agency of East Java Province. The vegetation type in the area is a natural forest (Figure 2).

\section{Procedures}

Sample collection

The first author conducted sampling. In total 24 quadrat sampling plots with the size of $10 \times 10 \mathrm{~m}^{2}$ were selected within the research area (Figure 2). Sampling activity combined visual observation (direct collection) and sieving-sorting $5 \mathrm{~kg}$ soil samples (Nurinsiyah et al. 2016; Wendebourg and Hausdorf 2019). Visual observation was conducted at each sampling plot by examining decayed wood, rocks (when available), tree trunks to search for arboreal snails, and the undersides of leaves. The main target for visual observation was to sample macro snails (snails > 10mm). The visual observations and direct collections were conducted for one hour for each plot. A $5 \mathrm{~kg}$ bag of leaf litter and topsoil was collected from each plot. Later, the leaf litter and soil collections were sieved and sorted at the Biosystematics Laboratory, Department of Biology, University of Airlangga, East Java. The sieving and sorting method targeted micro snails (snails $<10 \mathrm{~mm}$ ).

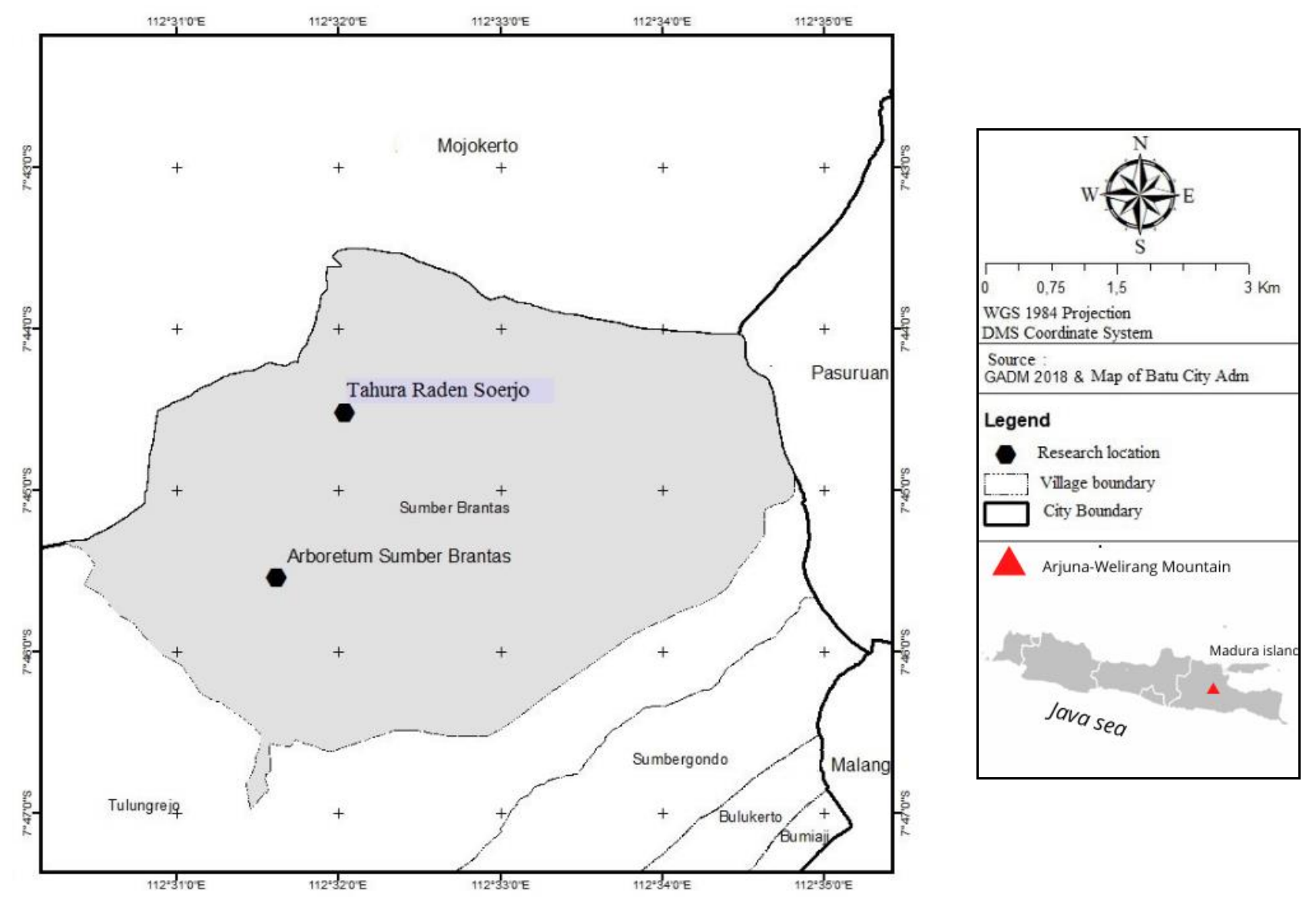

Figure 1. Map of sampling location in Sumber Brantas Village, slope area of Mount Arjuna-Welirang, East Java, Indonesia 

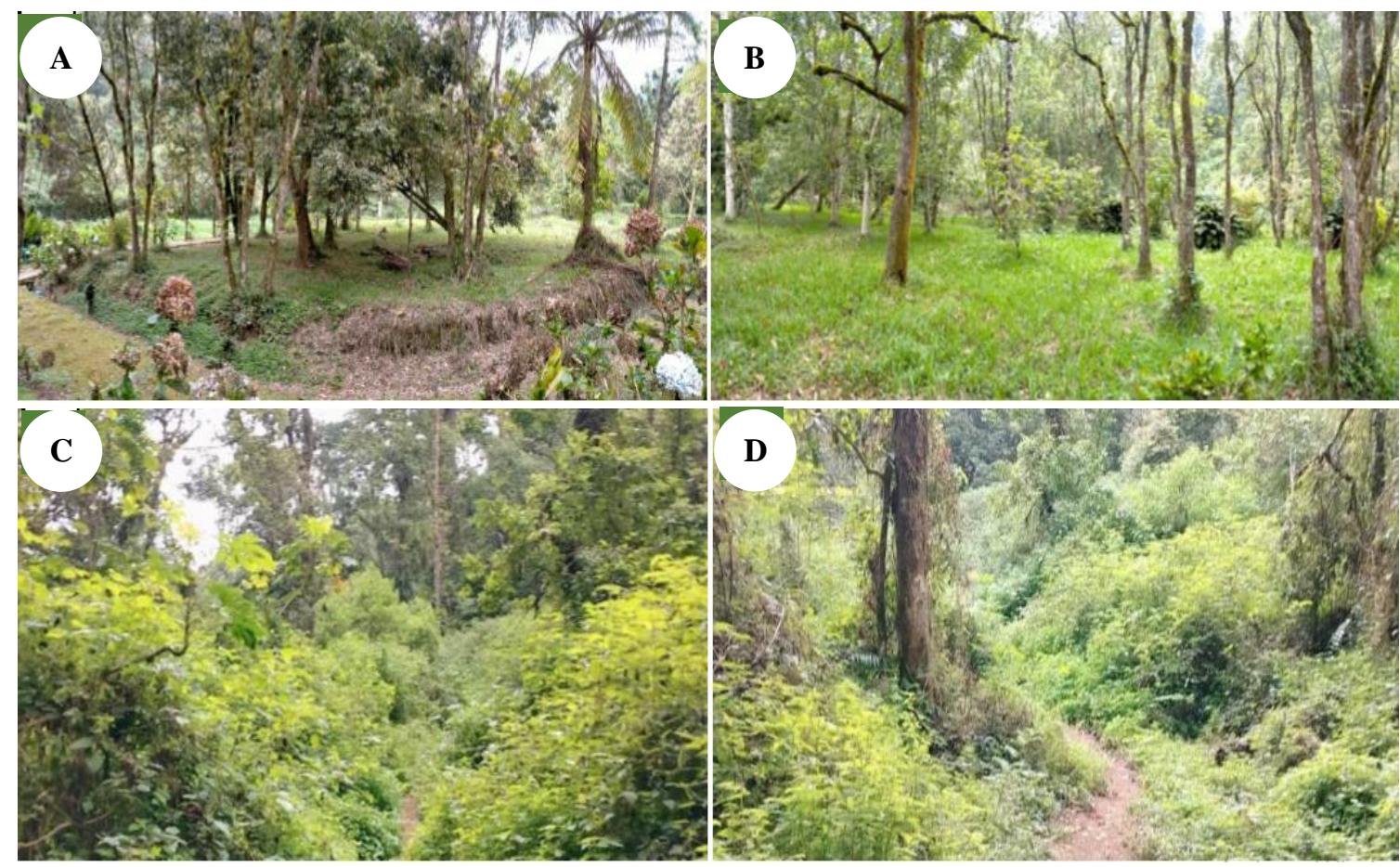

Figure 2. The habitats of the two sampling areas at Mount Arjuna-Welirang, East Java, Indonesia. (A,B) Arboretum Sumber Brantas; (C,D) Tahura Raden Soerjo

\section{Sample preparation}

Snails were classified into two groups: alive and dead. Only shells or shell fragments were found in the dead samples. All of the samples were cleaned with distilled water. Snail samples were directly transferred into collection bottles or tubes containing $70 \%$ alcohol. This was done to prevent the snail's fragile body from decaying. Meanwhile, the dead snail (shell) samples were cleaned with distilled water and dried. Afterward, the shells were stored in a tube or plastic bag with identification labels according to plots. This was a temporary label, and as soon as the samples were cleaned and identified, the specimens were catalogued. All collected specimens are preserved in the Museum Zoologicum Bogoriense (MZB), Research Center for Biology, National Research and Innovation Agency (BRIN).

\section{Identification of terrestrial gastropod samples}

Identification, validation, and visualization processes for the collected samples were conducted at MZB. The determination of land snail species referred to BenthemJutting (1948, 1950, 1952); Vermeulen and Whitten (1998); Dharma (2005); Heryanto (2011); Nurinsiyah and Hausdorf (2019); and Nurinsiyah et al. (2019a). The systematic arrangement of the determined Gastropods follows the classification of Bouchet et al. (2017) and Molluscabase.org. For the description of diagnostic characters, we measured shell height $(\mathrm{H})$, shell width (D), the height of aperture (ha), the width of aperture (da), and the number of whorls (W). An Olympus S2X7 stereomicroscope was used for species identification. Each species was photographed at three positions i.e. (i) with visible protoconch (apical view), (ii) with visible umbilicus (umbilical view), and (iii) with visible aperture (apertural/ lateral view). Photographs were compiled using a DMC5400 camera with L.A.S V4.13.0 software adapted to a Z6 APO (all from Leica Microsystems, Heerbrugg, Switzerland).

\section{Data analysis}

The terrestrial gastropod communities were analyzed by calculating relative species abundance, Shannon's diversity $\left(\mathrm{H}^{\prime}\right)$ index, and Simpson's dominance $(\mathrm{C})$ index (Odum 1971).

Relative abundance of species

$\mathrm{Ni}(\%)=(\mathrm{ni} / \mathrm{N}) .100 \%$

Shannon's Diversity index

$\mathrm{H}^{\prime}=-\sum[(\mathrm{ni} / \mathrm{N}) \cdot \ln (\mathrm{ni} / \mathrm{N})]$

Where:

H' : Shannon's diversity index based on abundance index

ni : individuals of species i

$\mathrm{N}$ : Total number of individuals

Criteria of the diversity index:

$\mathrm{H}<1$ : low diversity, unstable community, and low distribution

$1<\mathrm{H}<3$ : medium diversity, less stable community, and medium distribution

$\mathrm{H}<3$ : high diversity, stable community, and high distribution 
Simpson dominance index

$$
\mathrm{C}=\sum(\mathrm{ni} / \mathrm{N})^{2}
$$

Where:

$\mathrm{C}$ : Dominance index

ni : Number of individuals of each species

$\mathrm{N}$ : Number of individuals of all species

Criteria of dominance index:

$\mathrm{C}<0.5$ : low dominance

C $>0.5$ : high dominance

\section{RESULTS AND DISCUSSION}

\section{Results}

In total, 646 specimens were collected from 24 sampling plots. The number of collected specimens ranged from 1 to 187 specimens per plot. The number of species found per plot ranged between 1-6 species. The collected specimens belong to eight families and 13 species. All of the collected species represent new records for Mt. ArjunaWelirang. Therefore, the number of known species in the area increases to 16 species belonging to nine families (Table 1). The average light intensity in Arboretum and Tahura were 2383 and 1835, respectively. The Arboretum has an average of soil $\mathrm{pH} 6.3$ and an average of soil humidity 2.7, while the Tahura has an average of 6.4 and 2.3 for soil $\mathrm{pH}$ and soil humidity, respectively.

Table 1. Comparative species list for Mount Arjuna-Welirang, East Java, Indonesia

\begin{tabular}{|c|c|c|c|}
\hline Family & Species & $\begin{array}{c}\text { Current } \\
\text { Study }\end{array}$ & $\begin{array}{c}\text { Mentioned } \\
\text { by Benthem } \\
\text { Jutting } \\
(1948,1950, \\
1952) \\
\end{array}$ \\
\hline \multirow[t]{2}{*}{ Achatinidae } & Lissachatina fulica* & - & $\sqrt{ }$ \\
\hline & Paropeas acutissimum & - & $\sqrt{ }$ \\
\hline Cyclophoridae & Japonia ciliocincta & $\sqrt{ }$ & - \\
\hline \multirow[t]{2}{*}{ Charopidae } & Philalanka micromphala & $\sqrt{ }$ & - \\
\hline & Philalanka thienemanni & $\sqrt{ }$ & - \\
\hline Gastrocoptidae & Paraboysidia boettgeri & $\sqrt{ }$ & - \\
\hline \multirow{2}{*}{ Chronidae } & Kaliella barrakporensis & $\sqrt{ }$ & - \\
\hline & Kaliella platyconus & $\sqrt{ }$ & - \\
\hline \multirow[t]{2}{*}{ Euconulidae } & Coneuplecta sitaliformis & $\sqrt{ }$ & - \\
\hline & Liardetia convexiconica & $\sqrt{ }$ & - \\
\hline Helicarionidae & Helicarion albellus & $\sqrt{ }$ & - \\
\hline \multirow[t]{3}{*}{ Ariophantidae } & Macrochlamys infans & - & $\sqrt{ }$ \\
\hline & Microcystina nana & $\sqrt{ }$ & - \\
\hline & Parmarion pupillaris & $\sqrt{ }$ & - \\
\hline \multirow[t]{2}{*}{ Camaenidae } & Bradybaena similaris* & $\sqrt{ }$ & - \\
\hline & Landouria sp. & $\sqrt{ }$ & - \\
\hline
\end{tabular}

Note $: \sqrt{ }:$ found, (-) : not listed, *: invasive species

\section{List of species}

The species are listed systematically following Bouchet et al. (2017).

\section{Class Gastropoda \\ Subclass Caenogastropoda \\ Grade Architaenioglossa \\ Family Cyclophoridae}

\section{Japonia ciliocincta (Martens, 1865) - Figure 3}

Diagnosis $(\mathrm{n}=8)$ : Shell moderate size: $4.5-7.2 \mathrm{~mm}(\mathrm{H})$; 3.7-6.5 mm (D); 1.0-2.6 mm (ha); 1.0-2.6 mm (da). Shell trochiform, colour yellowish brown with brown flames, sometimes with hair, 6 whorls increasing in size. Periphery rounded with 3-4 keels, top whorl not smooth. Umbilicus not wide, aperture oblique, peristome continuous. Snail with round operculum.

Distribution in Java: Can be found throughout Java, mostly in the lowlands, but it also at higher elevations up to $1600 \mathrm{~m}$ a.s.l. (Tengger Mts.) (Benthem-Jutting 1948).

Examined materials: MZB.Gst.22144/2,

MZB.Gst.22145/1, MZB.Gst.22146/3,

MZB.Gst.22147/2.

Subclass Heterobranchia

Order Stylommatophora

Family Achatinidae

\section{Lissachatina fulica (Bowdich, 1822)}

Diagnosis: Shell very large size: $100-170 \mathrm{~mm}(\mathrm{H})$; $45-$ $60 \mathrm{~mm}$ (D); 50-55 mm (ha). Shell pyramidal shell, brownbased colour with darker streaks, 7-9 whorls increasing in size. Last whorl large and rounded, top whorl smooth. Umbilicus closed, aperture oblique, peristome not continuous (Benthem-Jutting 1952)

Distribution in Java: Widespread in Java, particularly areas with human activity and settlements.

Examined materials: Not collected. The historical record was based on literature (Benthem-Jutting 1952; Nurinsiyah and Hausdorf 2019).

Remarks: The species is known as Bekicot in Bahasa Indonesia. It is an invasive species to Indonesia and listed as one of the 100 most invasive species in the world by IUCN (Lowe et al. 2000; Nurinsiyah and Hausdorf 2019).

\section{Paropeas acutissimum (Mousson, 1857)}

Diagnosis: Shell with large size: $24-34 \mathrm{~mm}(\mathrm{H})$; 5-8 $\mathrm{mm}$ (D); 6-9 mm (ha). Shell long and slender, yellowish or green colour, 10-12 whorls increasing in size. Last whorl the longest than the rest of the whorl, top whorl smooth. Umbilicus closed, aperture oblique, peristome not continuous (Benthem-Jutting 1952).

Distribution in Java: Can be found throughout Java from lowlands (0 $\mathrm{m}$ a.s.l.) to highlands up to $2200 \mathrm{~m}$ a.s.1. (Mt. Gede and Dieng Plateau) (Benthem-Jutting 1952).

Examined materials: Not collected. The record was based on the literature (Benthem-Jutting 1952). 


\section{Family Charopidae}

Philalanka micromphala van Benthem-Jutting 1952 Figure 4

Diagnosis $(\mathrm{n}=3)$ : Shell micro-sized $(<10 \mathrm{~mm})$ : $1.2-2.0$ $\mathrm{mm}(\mathrm{H}) ; 2.6-2.9 \mathrm{~mm}(\mathrm{D}) ; 1.0 \mathrm{~mm}$ (ha); 1.0-1.2 $\mathrm{mm}$ (da). Shell low conical, greenish-yellow coloured and transparent, 4-5 whorls increasing in size. Last whorl carinated, top whorl not smooth. Umbilicus narrow, aperture quadrangular, peristome not continuous.

Distribution in Java: The species was only recorded from Mt. Cikuray (Benthem-Jutting 1952). The record on Mt. Arjuna-Welirang is an important finding.

Examined materials: MZB.Gst.22169/1,

MZB.Gst.22170/1, MZB.Gst.22171/1.

\section{Philalanka thienemanni Rensch, 1932 - Figure 5}

Diagnosis $(\mathrm{n}=4)$ : Shell micro-sized (<10 mm): 1.0-2.4 $\mathrm{mm}(\mathrm{H})$; $1.8-2.8 \mathrm{~mm}(\mathrm{D})$; 0.3-0.4 mm (ha); 0.3-0.4 mm (da). Shell conical, greenish-yellow or brown coloured and transparent, 5-6.5 whorls increasing in size. Last whorl carinated, top whorl not smooth. Umbilicus wide, aperture quadrangular-oblique, peristome not continuous.

Distribution in Java: Mostly found on mountains (high elevation from $1000 \mathrm{~m}$ a.s.1.) (Benthem-Jutting 1952).

Examined materials: MZB.Gst.22172/4.

\section{Family Gastrocoptidae}

Paraboysidia boettgeri (Möllendorff, 1897) - Figure 6

Diagnosis $(\mathrm{n}=1)$ : Shell micro-sized $(<10 \mathrm{~mm}): 7 \mathrm{~mm}$ (H); $5 \mathrm{~mm}$ (D); $2.5 \mathrm{~mm}$ (ha); $2 \mathrm{~mm}$ (da). Shell trochiform, brownish, 5-6 whorls. Last whorl ascending in front, periphery round, top obtuse, and base rounded. Shell with palatal folds and lamellae on the parietal and angular wall and on the columellar side. Umbilicus narrow, aperture slightly oblique, peristome continuous.

Distribution in Java: The species so far was only recorded in western Java. The record from Mt. ArjunaWelirang is an important finding (Benthem-Jutting 1952).

Examined materials: MZB.Gst.22166/1.

\section{Family Chronidae}

Kaliella barrakporensis (L. Pfeiffer, 1853) - Figure 7

Diagnosis $(\mathrm{n}=3)$ : Shell micro-sized $(<10 \mathrm{~mm}): 2.8-3.8$ $\mathrm{mm}(\mathrm{H})$; 2.5-3.3 mm (D); 0.5-1.2 mm (ha); 1.5-2.2 mm (da). Shell high conical, transparent yellow coloured, flat sides and base, 7 whorls are increasing in size. The last whorl keeled, top whorl not smooth. Umbilicus narrow, aperture rhombiform, peristome not continuous.

Distribution in Java: Widely distributed in the western part of Java. The central part of Java records is from Mt. Lawu, Kulonprogo, Gunungkidul, and Karangbolong. In East Java, the species has been recorded from the southern part of Malang (Benthem-Jutting 1950; Nurinsiyah et al. 2016). In addition, the recent record from Mt. ArjunaWelirang added to our knowledge of species in East Java.

Examined materials: MZB.Gst.22148/3.
Kaliella platyconus Möllendorff, 1897 - Figure 8

Diagnosis $(n=4)$ : Shell micro-sized $(<10 \mathrm{~mm}): 2.5-2.6$ $\mathrm{mm}(\mathrm{H})$; 3.2-3.5 mm (D); 1.5-1.8 $\mathrm{mm}$ (ha); 0.5-0.6 mm (da). Shell wide conical, flat sides, yellow coloured and transparent, 5.5-6 whorls increasing in size. The last whorl sharply keeled, top whorl not smooth. Umbilcus almost closed, aperture rhombiform oblique, peristome sharp.

Distribution in Java: Can be found at high elevation above $1000 \mathrm{~m}$ a.s.l. (Benthem-Jutting 1950).

Examined materials: MZB.Gst.22160/1, MZB.Gst.22161/3.

\section{Family Euconulidae}

Coneuplecta sitaliformis (Möllendorff, 1897) - Figure 9

Diagnosis $(\mathrm{n}=3)$ : Shell micro-sized $(<10 \mathrm{~mm})$ : 4.2-5.0 $\mathrm{mm}(\mathrm{H})$; 4.3-5.8 mm (D); 0.8-1.7 mm (ha); 0.9-2.0 mm (da). Shell high conical, brown and fragile, 5-5.5 whorls increasing in size. Last whorl the widest, top whorl smooth. Umbilicus almost closed, aperture oblique, peristome not continuous.

Distribution in Java: Can be found throughout Java but mostly at high elevations (above $1000 \mathrm{~m}$ a.s.l) (BenthemJutting 1950)

Examined materials: MZB.Gst.22127/3,

MZB.Gst.22128/1, MZB.Gst.22129/3,

MZB.Gst.22130/3, MZB.Gst. 22131/2,

MZB.Gst.22132/1, MZB.Gst.22133/2,

MZB.Gst.22134/2, MZB.Gst.22136/4.

\section{Liardetia convexoconica (Möllendorff, 1897) - Figure 10}

Diagnosis $(\mathrm{n}=7)$ : Shell micro-size $(<10 \mathrm{~mm}): 2.7-3.3$ $\mathrm{mm}(\mathrm{H}) ; 2.6-3.4 \mathrm{~mm}$ (D); 0.5-1.0 mm (ha); $1.0-1.5 \mathrm{~mm}$ (da). Shell high conical, brownish and transparent, 5-6 whorls increasing in size. The last whorl keeled, top whorl smooth. Umbilicus narrow, aperture rhombiform, peristome sharp.

Distribution in Java: Can be found throughout Java from lowland ( $0 \mathrm{~m}$ a.s.l.) to highland up to $2400 \mathrm{~m}$ a.s.l. (Mt. Pangrango) (Benthem-Jutting 1950).

Examined materials: MZB.Gst. 22162/5, MZB.Gst. $22163 / 8$.

\section{Family Helicarionidae}

\section{Helicarion albellus Martens, 1867 - Figure 11}

Diagnosis $(\mathrm{n}=10)$ : Shell moderate size: $2.6-3.9 \mathrm{~mm}(\mathrm{H})$; 4.7-7.5 mm (D); 0.9-1.2 mm (ha); 0.8-1.2 mm (da). Shell globular, brown with the reddish zone (sometimes whitish) along the suture, 4-5 whorls increasing in size. Last whorl carinated, top whorl not smooth. Umbilicus closed, aperture oblique, peristome not continuous and sharp.

Distribution in Java: Can be found throughout Java from lowland (0 $\mathrm{m}$ a.s.l.) to highland up to $2000 \mathrm{~m}$ a.s.l. (Mt. Gede) (Benthem-Jutting 1950).

Examined materials: MZB.Gst.22137/3,

MZB.Gst.22138/4, MZB.Gst.22139/3,

MZB.Gst.22140/8, MZB.Gst.22141/12,

MZB.Gst.22142/2, MZB.Gst.22143/11. 
Family Ariophantidae

Microcystina nana (Möllendorff, 1897)- Figure 12

Diagnosis $(\mathrm{n}=3$ including jouvenile): Shell micro-sized (<10 mm): $0.5-1.0 \mathrm{~mm}(\mathrm{H}) ; 1.0-2.0 \mathrm{~mm}$ (D); 0.3-0.5 mm (ha); 0.2-0.5 mm (da). Shell flat, yellowish coloured and transparent, 3.5-5 whorls increasing in diameter. Last whorl rounded, top whorl slightly elevated. Umbilicus narrow, aperture oblique, peristome not continuous.

Distribution in Java: Can be found throughout Java from lowlands ( $0 \mathrm{~m}$ a.s.l.) to highlands up to $2800 \mathrm{~m}$ a.s.l (Mt. Gede) (Benthem Jutting 1950).

Examined materials: MZB.Gst.22164/1, MZB.Gst.22165/12.

\section{Macrochlamys infans (L. Pfeiffer, 1854)}

Diagnosis: Shell moderate size: $5.5-7.0 \mathrm{~mm}(\mathrm{H})$; 9.0$11.0 \mathrm{~mm}$ (D); 4.0-5.0 mm (ha). Shell low conical, brownish-yellow coloured, 5-5.5 whorls increasing in diameter. The last whorl rounded and smooth, top whorl projecting. Umbilicus open but not wide, aperture oblique, peristome not continuous (Benthem-Jutting 1950).

Distribution in Java: Can be found at high elevations from $700 \mathrm{~m}$ a.s.l. (Benthem-Jutting 1950).

Examined materials: Not collected. The record was based on literature under the name Lamprocystis infans (Benthem-Jutting 1950).

\section{Parmarion pupillaris Humbert 1864 - Figure 15}

Diagnosis: A semi slug species. Shell length up to 15 $\mathrm{mm}$ and width up to $11 \mathrm{~mm}$. Shell flat and nail-like shaped, without apparent whorl. Body with dark grey to a black color and three longitudinal zones on the bottom side of the foot (dark grey on each peripheral zone and light grey on the central zone).

Distribution in Java: Can be found throughout Java from lowland (0 m a.s.l) to highlands up to $2800 \mathrm{~m}$ a.s.l (Mt. Lawu) (Benthem-Jutting 1950).

Examined materials:

MZB.Gst.22167/3, MZB.Gst.22168/2.

\section{Family Camaenidae}

Bradybaena similaris (Férussac, 1821) - Figure 13

Diagnosis $(\mathrm{n}=10)$ : Shell large size: $6.4-9.5 \mathrm{~mm}(\mathrm{H})$; 9.8-13 mm (D); 3.8-5.7 mm (ha); 4.3-6.9 mm (da). Shell globular, reddish-brown, sometimes with dark brown peripheral band, 4-5.5 whorls increasing in size. The last whorl rounded, top whorl not smooth. Umbilicus open, aperture sickle-shaped, peristome not continuous.

Distribution in Java: Present in almost all areas of Java, especially with plantations, outcrops and human settlements. It is listed as an invasive species in Indonesia (Benthem-Jutting 1950; Nurinsiyah and Hausdorf 2019).

Examined materials: MZB.Gst.22111/14,

MZB.Gst.22112/14, MZB.Gst.22113/2,

MZB.Gst.22114/27, MZB.Gst.22115/39,

MZB.Gst.22116/12, MZB.Gst.22117/61,

MZB.Gst.22118/44, MZB.Gst.22119/12,

MZB.Gst.22120/23, MZB.Gst.22121/15,

MZB.Gst.22122/158, MZB.Gst.22123/15,
MZB.Gst.22124/13, MZB.Gst.22125/14, MZB.Gst.22126/7.

\section{Landouria sp. - Figure 14}

Diagnosis $(\mathrm{n}=10)$ : Shell moderate size: $2.3-4.1 \mathrm{~mm}(\mathrm{H})$; 5.8-8.5 mm (D); 0.2-1.4 mm (ha); 0.3-2.9 mm (da). Shell low conical or flat, colour yellowish-brown, 6 whorls increasing in size. Last whorl carinated, top whorl not smooth. Umbilicus wide, aperture oblique, peristome not continuous.

Distribution: Probably endemic to Java.

Remarks: based on the shell morphology, the specimen belongs to the genus Landouria. Its shell characters are similar to those of Landouria monticola van BenthemJutting, 1950. However, L. monticola is considered endemic to Mt. Cikuray, West Java. A previous study revealed a juvenile paratype of " $L$. monticola" collected from Mt. Kawi, East Jawa, with a different morphologicalcharacters with $L$. monticola from Mt. Cikuray. The specimen is preserved in the Zoologisches Museum Amsterdam (ZMA,). Some Landouria can be distinguished based on shell characters but for many, anatomical and DNA examination are mandatory (Nurinsiyah et al. 2019a). Therefore, the species found in Mt. Arjuna-Welirang is an important finding, but the determination to species level is not possible because only empty shells have been collected so far.

Examined materials: MZB.Gst.22149/10,

MZB.Gst.22150/1, MZB.Gst.22151/1,

MZB.Gst.22152/6, MZB.Gst.22153/19,

MZB.Gst.22154/5, MZB.Gst.22156/10,

MZB.Gst.22157/3, MZB.Gst.22158/1,

MZB.Gst.22159/1.

The Mt. Arjuna-Welirang slope showed a medium diversity value of 1.1 (Shannon diversity index). The Simpson's dominance index was 0.54 , suggesting medium dominance. Species found in the Sumber Brantas Arboretum are more abundant compared to the Tahura area. However, the land snail species in the latter area are more diverse. The high number of individuals and the low number of species in the Sumber Brantas Arboretum are indicators of the low diversity in the area. This is supported by the value of Shannon's diversity index of 0.38 and a dominance index of 0.85 . The latter index suggests the presence of a dominant species. Bradybaena similaris showed the highest abundance, with $92 \%$ of the total species abundance found in the Sumber Brantas Arboretum.

On the other hand, although the species abundance in Tahura is lower than in the Arboretum, the total species richness is higher. A total of 13 species were found with varying abundance percentages (Table 2). The terrestrial gastropod abundance with the highest percentage in Tahura was Landouria sp. (27.5\%) and Helicarion albellus $(26.8 \%)$. There is no dominant species in Tahura, which is supported by the value of Simpson's dominance index (< $0.5)$. Shannon's diversity index was 2.0 , which suggesting a medium diversity in the area (Table 2). 


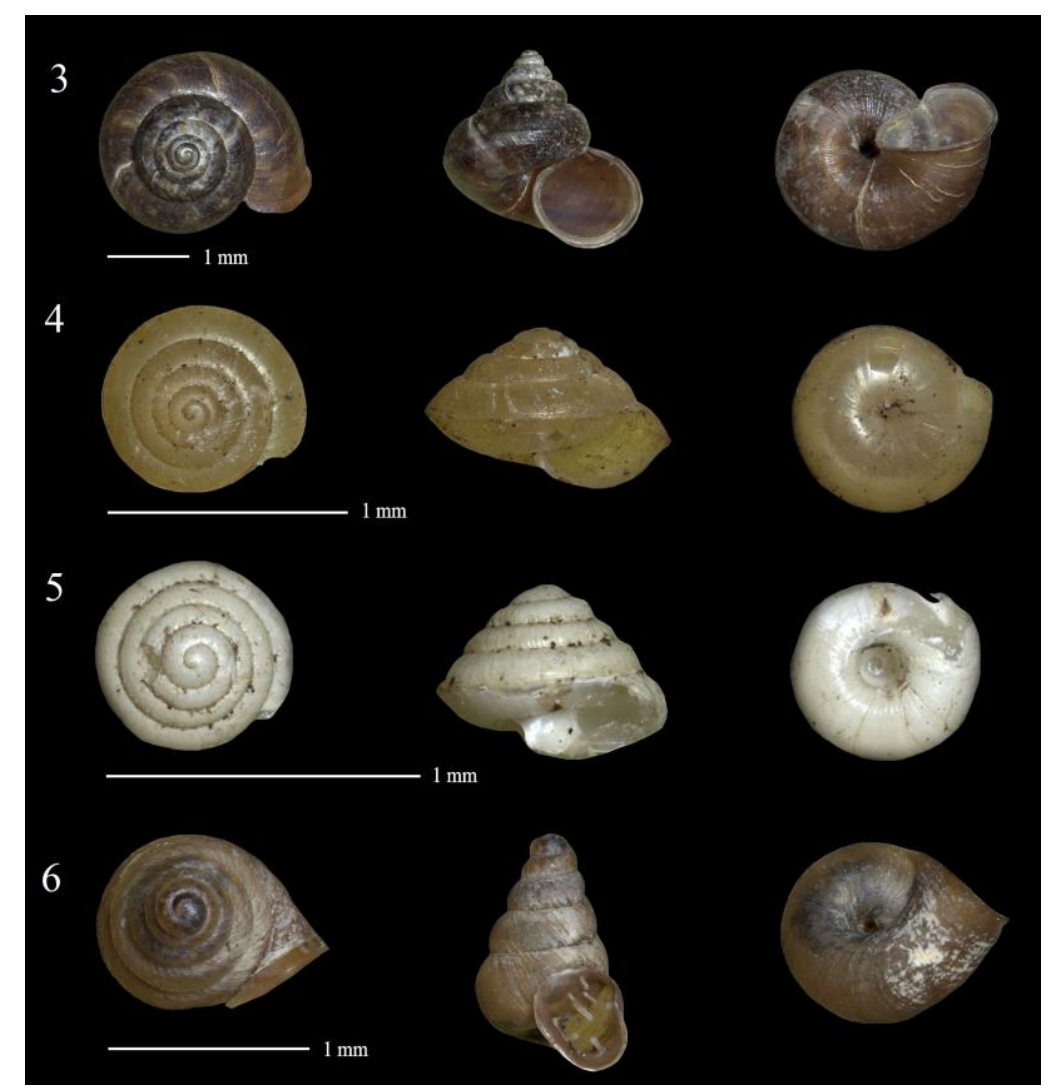

Figure 3-6. 3. Japonia ciliocincta (MZB.Gst.22145), 4. Philalanka micromphala (MZB.Gst.22170), 5. Philalanka thienemanni (MZB.Gst.22172), 6. Paraboysidia boettgeri (MZB.Gst.22166)

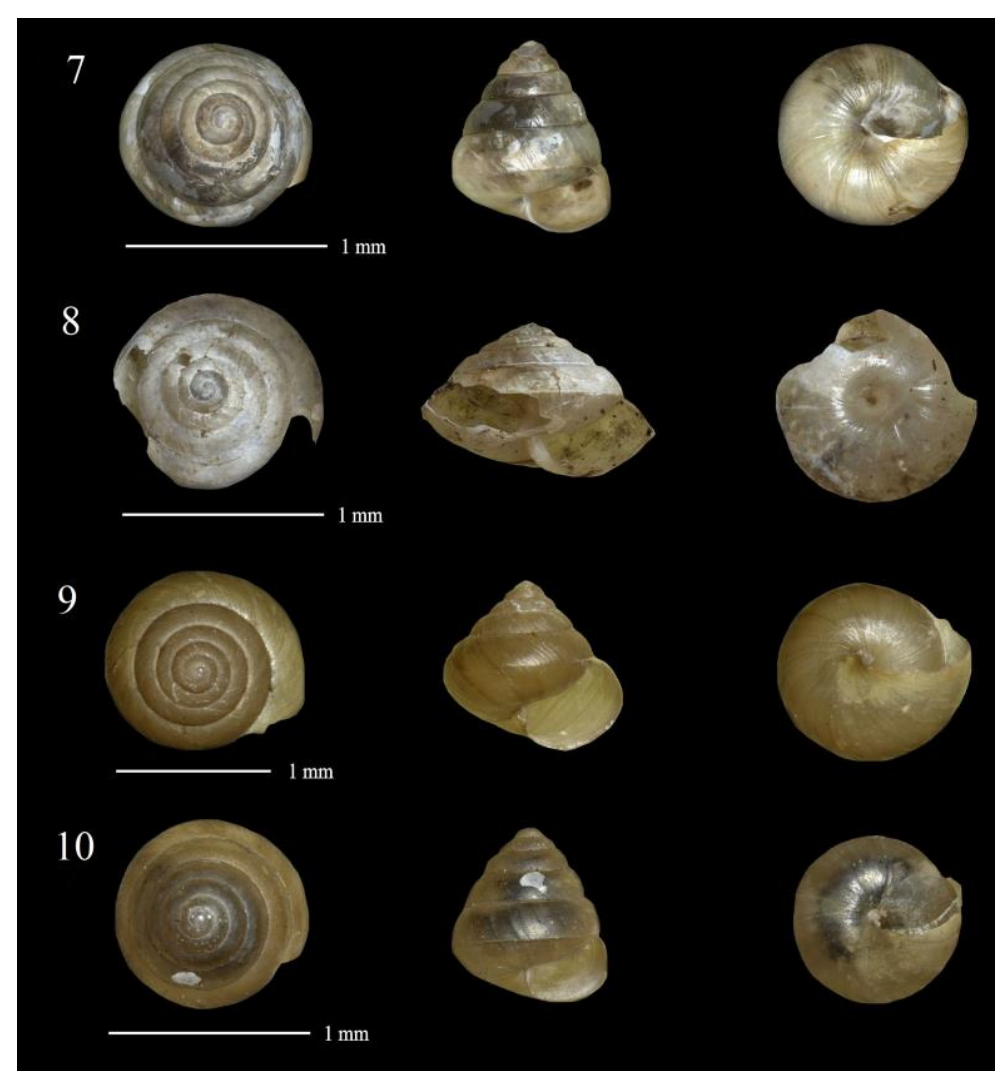

Figure 7-10. 7. Kaliella barrakporensis (MZB.Gst.22148), 8. Kaliella platyconus (MZB.Gst.22160), 9. Coneuplecta sitaliformis (MZB.Gst.22130), 10. Liardetia convexoconica (MZB.Gst.22163) 


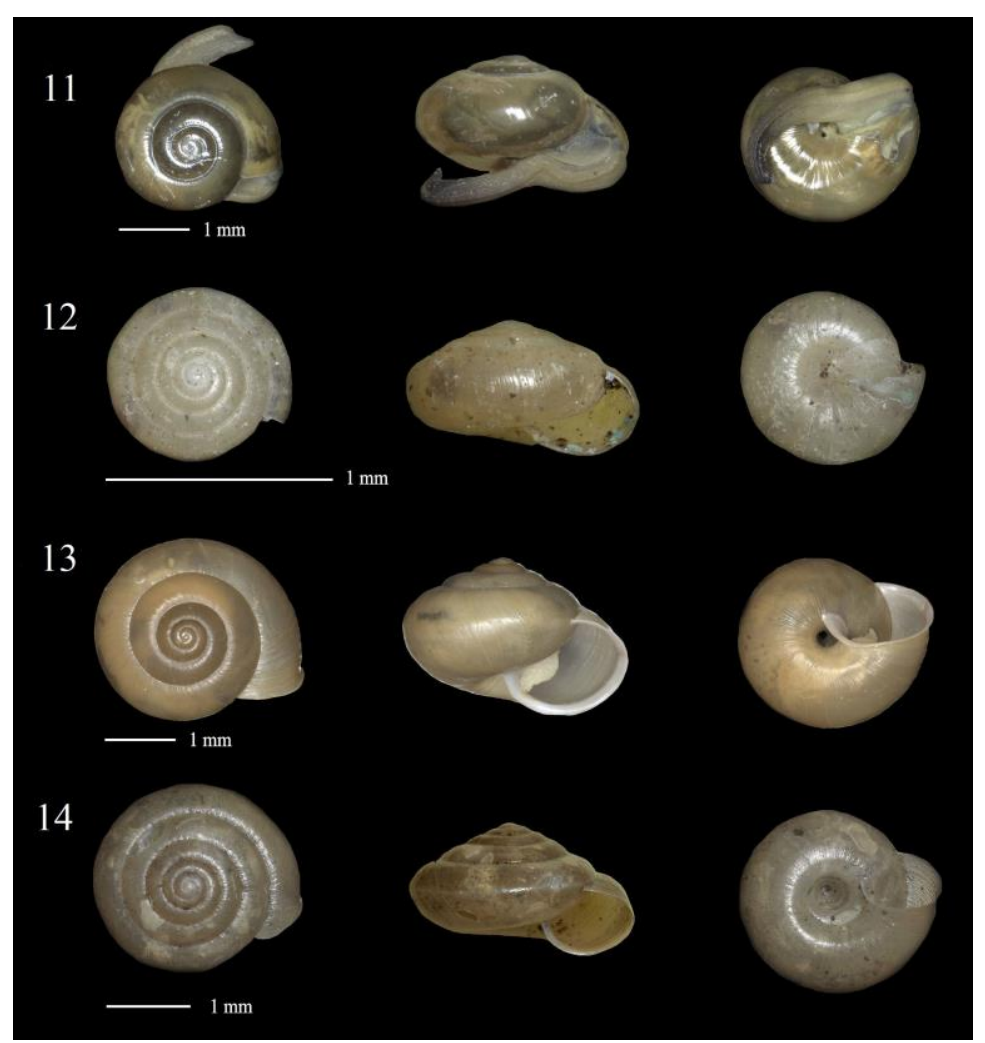

Figure 11-14. 11. Helicarion albellus (MZB.Gst.22139), 12. Microcystina nana (MZB.Gst.22164), 13. Bradybaena similaris (MZB.Gst.22122), 14. Landouria sp (MZB.Gst.22153)

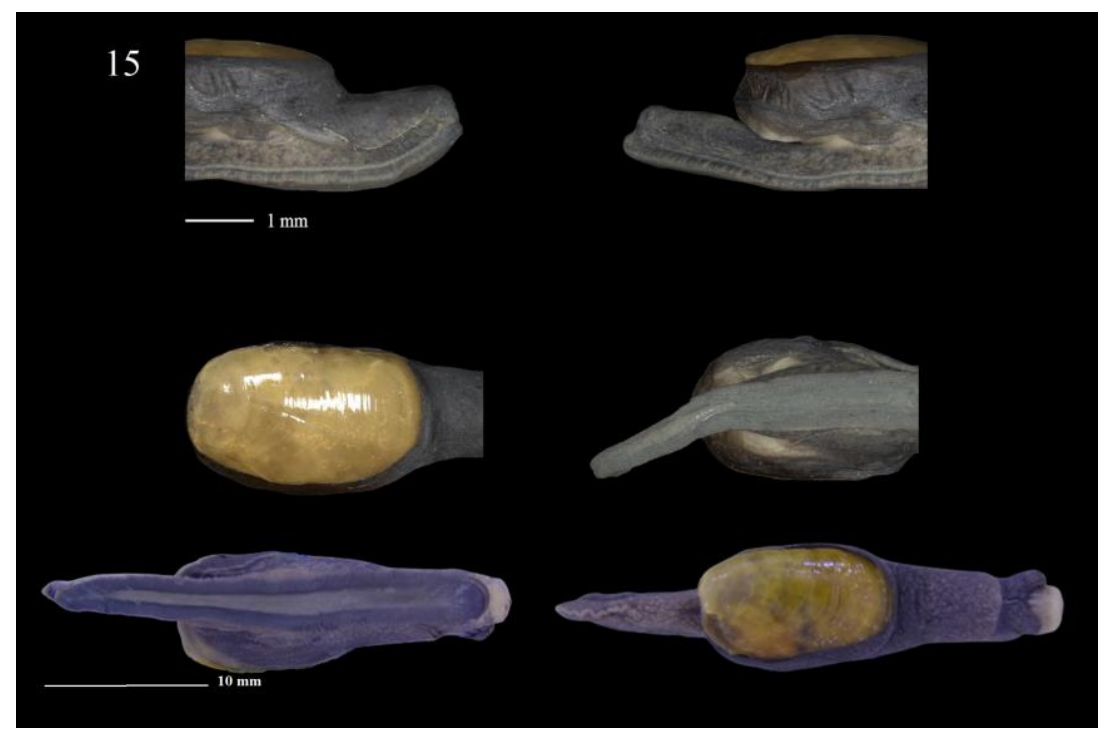

Figure 15. Parmarion pupillaris (MZB.Gst.22135)

\section{Discussion}

Volcanic soil is often less favorable for land snails in the tropics. Although these areas show high land snail diversity and endemism, there is less abundance. Most conservation areas in Java were volcanic areas. In addition, only 5\% of Java Island is covered by natural forests (Purba et al. 2014), where most of the remaining natural forests are designated as conservation areas. Based on the present study and previous records, there are 16 species of land snails in Mt. Arjuna-Welirang. Research on land snail diversity in volcanic and conservation areas in Java has been conducted in different parts of Java. In the western part of Java, 48 species of land snails were recorded from Mt. Ciremai (Heryanto 2008), 36 species from Mt. Sawal, and 19 species from Mt Galunggung (Heryanto 2017). 
Table 2. Community structure of terrestrial Gastropods in sampling areas of Arboretum Sumber Brantas and Tahura Raden Soerjo, East Java, Indonesia

\begin{tabular}{|c|c|c|c|c|}
\hline \multirow{2}{*}{ Species } & \multicolumn{2}{|c|}{ Arboretum } & \multicolumn{2}{|c|}{ Tahura } \\
\hline & ni & $\mathrm{Ni}(\%)$ & ni & $\mathrm{Ni}(\%)$ \\
\hline Microcystina nana & - & - & 13 & 8.1 \\
\hline Parmarion pupillaris & 4 & 0.8 & 2 & 1.3 \\
\hline Bradybaena similaris & 447 & 92.0 & 23 & 14.4 \\
\hline Landouria sp. & 13 & 2.7 & 44 & 27.5 \\
\hline Philalanka micromphala & - & - & 3 & 1.9 \\
\hline Philalanka thienemanni & - & - & 4 & 2.5 \\
\hline Kaliella barrakporensis & - & - & 3 & 1.9 \\
\hline Japonia ciliocincta & - & - & 8 & 5.0 \\
\hline Coneuplecta sitaliformis & 17 & 3.5 & 4 & 2.5 \\
\hline Liardetia convexiconica & 5 & 1.0 & 8 & 5.0 \\
\hline Kaliella platyconus & - & - & 4 & 2.5 \\
\hline Paraboysidia boettgeri & - & - & 1 & 0.6 \\
\hline Helicarion albellus & - & - & 43 & 26.8 \\
\hline Number of specimens & & 486 & & 60 \\
\hline Number of species (s) & & 5 & & 13 \\
\hline Shannon Diversity Index & & 0.38 & & 2.0 \\
\hline Simpson Dominance Index & & 0.85 & & 18 \\
\hline
\end{tabular}

Total 376 specimens were recorded in Telaga Warna Nature Tourism Park (TWA), which belong to 11 species (Wijaya et al. 2019). The species richness was lower than land snail diversity in the Gunung Halimun Salak National Park, where Nurinsiyah et al. (2019b) recorded 399 specimens belonging to 43 species. A previous study in Mt. Semeru, a volcanic and conservation area in East Java, recorded 12 land snail species (Nurhayati et al. 2020).

There are at least 1863 land snail species in the IndoAustralian Archipelago (Hausdorf 2019). The list was based on records from 28 islands and Peninsular Malaysia, mostly found in Indonesia. Land snails can be found in various elevations and landscapes, from karst to volcanic substrates, and they tend to occur more in the former. Phung et al. (2018) documented 47 land snail species from only five sampling plots of $2 \times 4 \mathrm{~m}$ in Gunung Kuang, Malaysia. Nurinsiyah and Hausdorf (2020) recorded 34 species from only eight sampling plots of $10 \mathrm{~m} \times 10 \mathrm{~m}$ in Mt. Ciampea, West Java. Meanwhile, Mujiono and Priawandiputra (2020) recorded 35 species of land snails from 12 different stations in Java.

The number of species recorded from the slope of Mt. Arjuna-Welirang was 13 species, with all 13 species were recorded in Tahura, and five species were recorded in Arboretum. Less canopy cover and more human activity in the Arboretum are likely to contribute to this species diversity difference. The Tahura area is covered with secondary forest. Meanwhile, the Arboretum includes many trees planted for touristic purposes, some non-native to the area. Identified vegetation in the Arboretum area includes shrubs, pines, mahogany, palm, banana, and various flowering plants. As a consequence, the Arboretum area has less canopy coverage compared to Tahura. In addition, the Arboretum is located near Sumber Brantas Village. The villagers use the areas near the Arboretum to plant vegetable crops such as cabbage, carrots, and mustard greens.

Three land snails recorded in 1952 were not found in the present study, i.e., L. fulica, P. acutissimum and M. infans. Given that the current study only focused on two locations with 24 plots, there is a possibility that the species occurs in other parts of Mt. Arjuna-Welirang. Among the known species from the area, there are two invasive species recorded in the area. Based on the literature study, one invasive species (Lissachatina fulica) was recorded in Mt. Arjuna-Welirang. The present study added another invasive species to the area, Bradybaena similaris, which occurs abundantly in the Arboretum. The species often occurs in plantations and agroforests. The species distribution is so widespread and frequent that their eradication in the area and in Java is not feasible (Nurinsiyah and Hausdorf 2019). Land-use change and lower canopy cover density may also lead to the flourishing of invasive species in tropical rainforest areas. These invasive species mostly have a higher tolerance for desiccation and thus can survive in a more open area (low density of canopy coverage). Deforestation and land-use changes have led to an increased number of introduced species in Java (Nurinsiyah et al. 2016).

Land snails tend to have small geographic ranges, sensitive to changes associated with human disturbance, and are, thus, especially prone to extinction by habitat destruction (Schilthuizen 2004; Douglas et al. 2013). Furthermore, habitat modification by humans will affect the diversity of native species and might increase the abundance of invasive species (Didham et al. 2007). The most significant threats to forest areas in Java today are anthropogenic factors, especially land conversions (forest destruction). In addition, the existence of native forest species is also endangered by hunting/trade, invasive alien species, and climate change (Hughes 2017). Therefore, minimizing habitat changes and human activity is necessary to maintain or increase native land snail diversity, especially in the slope of Mt. Arjuna-Welirang.

The number of species recorded in Mt. ArjunaWelirang may underestimate the actual species richness in the area. However, the present study has provided important and more complete baseline malacological data of Mt. Arjuna Welirang compared to the 1950s studies. More extensive research will help estimate species diversity accurately and better understand environmental factors related to this diversity. It would also be necessary to measure the environmental factors for suitable area management. Regular monitoring activity of the biodiversity in this area will indicate the forest quality and, therefore, will give a better understanding of the forest change.

\section{ACKNOWLEDGEMENTS}

We are very grateful to Galuh Ayu Cantika Dwitara (University of Airlangga) and Boni Herdiawan (University of Surabaya) for the help during fieldwork; Ristiyanti Marwoto (Museum Zoollogicum Bogoriense) as well as the 
Museum Zoologicum Bogoriense staff for the help in the laboratory. We are also very grateful to Rebecca J. Rundell (State University of New York) for proofreading the manuscript. We are sincerely thankful to Liew Thor Seng (Universiti Malaysia Sabah) and four other anonymous reviewers who provided critical suggestions and recommendations to improve this manuscript. The research was conducted follows the permit and procedure issued by Perum Jasa Tirta I No. 0288/UM/DJA I/IX/2020 and Raden Soerjo Forest Conservation Park Area No. 070/592/123, 7/2020.

\section{REFERENCES}

Benthem-Jutting WSS. 1948. Systematic studies on the non-marine Mollusca of the Indo-Australian Archipelago. Treubia 19(3): 539604.

Benthem-Jutting WSS. 1950. Systematic studies on the non-marine Mollusca of the Indo-Australian Archipelago. Treubia 20(3): 381505.

Benthem-Jutting WSS. 1952. Systematic studies on the non-marine Mollusca of the Indo-Australian Archipelago. Treubia 21(2): 291485.

Bouchet P, Rocroi JP, Hausdorf B, Kaim A, Kano Y, Nützel A, Parkhaev P, Schrödl M, Strong EE. 2017. Revised classification, nomenclator and typification of Gastropod and Monoplacophoran families. Malacologia 61(1-2): 1-526. DOI: 10.4002/040.061.0201

Dharma B. 2005. Recent \& Fossil Indonesian Shells. ConchBooks, Jakarta. [Indonesian]

Didham RK, Tylianakis JM, Gemmell NJ, Rand TA, Ewers RM. 2007. Interactive effects of habitat modification and species invasion on native species decline. Trends Ecol Evol 22(9): 489-496. DOI: 10.1016/j.tree.2007.07.001.

Douglas DD, Brown DR, Pederson N. 2013. Land Snail diversity can reflect degrees of anthropogenic disturbance. Ecosphere 4(2): 1-14. DOI: $10.1016 /$ j.tree.2007.07.001.

Foon JK, Clements GR, Liew TS. 2017. Diversity and biogeography of Land Snails (Mollusca, Gastropoda) in the Limestone Hills of Perak, Peninsular Malaysia. Zookeys 682: 1-94. DOI: 10.3897/zookeys.682.12999.

Greke K. 2019. New species and record of Diplommatina Benson, 1849 (Gastropoda: Diplommatinidae) from Java, Indonesia. Nautilus 133(1): 14-21

Hausdorf B. 2019. Beyond Wallace's line - dispersal of Oriental and Australo-Papuan Land-Snails across the Indo-Australian Archipelago. Zool J Linnean Soc 185: 66-76. DOI: 10.1093/zoolinnean/zly031.

Heryanto, Ristiyanti MM, Munandar A, Susilowati P. 2003. Conch from Mount Halimun National Park, a field guide: Biodiversity conservation project. Zoo Indonesia 29(2): 103-150. DOI: 10.52508/zi.v29i2.4037. [Indonesian]

Heryanto. 2008. The Ecology of the Land Conch in Mount Ciremai National Park. Indones Biol J 4(5): 359-370.

Heryanto. 2011. Land Snails of Java. LIPI Press, Bogor. [Indonesian]

Heryanto. 2017. The Land Snail diversity in succession forest of Mount Galunggung and Stable Forest of Mount Sawal, West Java. Zoo Indonesia 26(2): 59-69.

Hughes A. 2017. Understanding the drivers of Southeast Asian biodiversity loss. Ecosphere 8(1): 1-33. DOI: 10.1002/ecs2.1624.

Lowe S, Browne M, Boudjelas S, De Poorter M. 2000. 100 of the World's Worst Invasive Alien Species A selection from the Global Invasive
Species Database. The Invasive Species Specialist Group (ISSG) IUCN, Hollands Printing Ltd, Auckland.

Maassen WJM. 2000. Notes on terrestrial Molluscs of Sumatra, Indonesia, with descriptions of ten new species (Gastropoda, Prosobranchia \& Pulmonata). Basteria 64: 137-150.

Marwoto RM. 2008. A note on the distribution of the limestone snail Discartemon planus (Fulton, 1899) in Sulawesi - Indonesia (Gastropoda: Streptaxidae). Basteria 72: 191-194. DOI: 10.52508/zi.v25i1.3027.

Marwoto RM. 2016. The occurrence of the terrestrial Snail from Sumatra (Mollusca, Gastropods). Zoo Indonesia 25(1): 8-21

Mujiono N, Priawandiputra, W. 2020. Land Snail from Limestone Karst in Java: An update with notes on their distribution. IOP Conf Series Earth Environ Sci 457(012002): 1-9. DOI: 10.1088/17551315/457/1/012002.

Nurhayati PA, Herdiawan B, Dwitara GAC. 2020. Inventory of Land Snail in Darungan Lake, Bromo Tengger Semeru National Park 2019. Biota 6(1): 42-44. DOI: 10.19109/Biota.v6i1.5219. [Indonesian]

Nurinsiyah AS, Fauzia H, Hennig C, Hausdorf B. 2016. Native and introduced Land Snail species as ecological indicators in different land-use types in Java. Ecol Indic 70: 557-565. DOI: 10.1016/j.ecolind.2016.05.013.

Nurinsiyah AS, Hausdorf B. 2017a. Dicharax (?) candrakirana n. sp. (Gastropoda: Cyclophoridae) from Sempu Island, Indonesia. Zootaxa 4363(4): 589-591. DOI: 10.11646/zootaxa.4363.4.12.

Nurinsiyah AS, Hausdorf B. 2017b. Revision of the Diplommatinidae (Gastropoda: Cyclophoroidea) from Java. Zootaxa 4312(2): 201-245. DOI: 10.11646/zootaxa.4312.2.1.

Nurinsiyah AS. 2018. Land snails of Java: a study on systematics, ecology, and biogeography. [Dissertation]. University Hamburg, Hamburg. [Germany]

Nurinsiyah AS, Hausdorf B. 2019. Listing, impact assessment and prioritization of introduced land snail and slug species in Indonesia. J Molluscan Stud 85: 92-102. DOI: 10.1093/mollus/eyy062.

Nurinsiyah AS, Neiber MT, Hausdorf B. 2019a. Revision of the Land Snail genus Landouria Godwin-Austen, 1918 (Gastropoda, Camaenidae) from Java. Eur $\mathrm{J}$ Taxon 526: 1-73. DOI: 10.5852/ejt.2019.526.

Nurinsiyah AS, Faizah I, Prasetio Y, Setiadi T, Marwoto, RM, Hausdorf, B. 2019b. Diversity and ecology of Land Snails in Gunung Halimun Salak National Park (GHSNP) in Java, Indonesia. Zoo Indonesia 28(1): 46-58. DOI: 10.52508/zi.v28i1.3956.

Nurinsiyah AS, Hausdorf B. 2020. Changes in the composition of the Land Snail Fauna of Mt. Ciampea, West Java, Indonesia. BIO Web Conf 19: 1-5. DOI: 10.1051/bioconf/20201900018.

Odum EP. 1971. Fundamentals of Ecology. 3rd ed. W.B. Saunders Co., London.

Phung CC, Yong YZ, Said MAM, Liew TS. 2018. Land Snail fauna in Gunung Kuang Limestone Hill, Perak, Malaysia and its Conservation Implications (Mollusca, Gastropoda). ZooKeys 769: 1-11. DOI: 10.3897/zookeys.769.25571.

Purba CPP, Nanggara SG, Ratriyono M, Apriani I, Rosalina L, Sari NA, Meridian AH. 2014. Portrait of the State of Indonesia's Forests for the Period 2009-2013. Forest Watch Indonesia, Bogor. [Indonesian]

Schilthuizen M. 2004. Land Snail conservation in Borneo: Limestone outcrops act as arks. J Conchol 3: 149-154.

Vermeulen JJ, Whitten AJ. 1998. Fauna Malesiana Guide to the Land Snails of Bali. Backhuys Publishers, Leiden.

Wendebourg B, Hausdorf B. 2019. The Land Snail fauna of a South American Rainforest Biodiversity Hotspot: The Panguana Conservation Area in the Peruvian Amazon. J Molluscan Stud 85: 311-318. DOI: 10.1093/mollus/eyz014.

Wijaya WA, Sukandar P, Meitiyani. 2019. Diversity of Land Conch in Telaga Warna Natural Tourism Park, Bogor, West Java. Bioeduscience 3(1): 14-22. DOI: 10.29405/j.bes/3114-223161. [Indonesian] 